\title{
KAJIAN KELAYAKAN OPERASI PECAH BEBAN PENYULANG BETA (SJ-2) UNTUK KEHANDALAN SISTEM KELISTRIKAN KOTA BITUNG
}

\author{
Ilham Amu 1), Yasin Mohamad ${ }^{2)}$, Ade Irawaty Tolago ${ }^{3)}$ \\ ${ }^{123}$ Prodi Teknik Elektro Universitas Negeri Gorontalo \\ E-mail : ilhamamu_angk14@gmail.com, yasinmohamad@ung.ac.id, \\ adeirawty75@ung.ac.id
}

\begin{abstract}
ABSTRAK
Penelitian ini berjudul Kajian Kelayakan Operasi Pecah Beban Penyulang Beta SJ-2 untuk Kehandalan Sistem Kelistrikan Kota Bitung, kajian ini dilakukan untuk mengatasi permasalahan kelistrikan yang terjadi pada penyulang beta (SJ-2) yang berada pada wilayah kelistrikan kota bitung, dimana Jatuh Tegangan ujung yang sudah mendekati batas minimum dari standar tegangan yang telah ditetapkan oleh PT PLN yakni +5 dan -10\% dengan menggunakan 3 Alternatif pecah beban yakni : Overshock Jaringan, Uprating Jaringan Dan Pembanguana Jaringan Baru.

Kajian kelayakan operasi ini dibuat berdasarkan pengumpulan data yang dilakukan di wilayah kerja PT PLN (PERSERO) Rayon Bitung dengan cara melakukan pengukuran pada setia arus sisi sekunder yang ada trafo distribusi yang ada pada penyulang Beta (SJ-2). Setelah data terkumpul maka dilakukan simulasi dengan menggunakan Software Etap 12.6.

Berdasarkan simulasi yang dilakukan dengan menggunakan 3 alternatif pecah beban, maka didapati hasil tegangan ujung yang terbaik dengan menggunakan alternatif pembangunan jaringan baru dengan nilai tegangan mencapai $19.053 \mathrm{KV}$ dari nilai tegangan sebelum yakni $18.636 \mathrm{KV}$.
\end{abstract}

Kata Kunci : Kajian Kelayakan Operasi, Pecah Beban, Jatuh Tegangan.

\section{PENDAHULUAN}

Listrik merupakan salah satu kebutuhan masyarakat yang sangat penting dan sebagai sumber daya ekonomis yang paling utama yang dibutuhkan dalam suatu kegiatan. Seiring dengan perkembangan dan kemajuan teknologi,pembangunan teknologi industri berkaitan erat dengan tenaga listrik yangmerupakan salah satu faktor penting yang sangat mendukung perkembangan pembangunan khususnya sektor industri. P.T PLN (Persero) merupakan BUMN yang menyediakan tenaga listrik bagi seluruh lapisan masyarakat yang semakin hari semakin dibutuhkan keberadaannya. Hal ini tidak lepas dari kebutuhan masyarakat akan tenaga listrik yang semakin meningkat seiring dengan meningkatnya kemajuan teknologi dan taraf hidup masyarakat pada umumnya.

Di kota Bitung sendiri saat ini memiliki 9 penyulang sebagai jalur pendistribusian tenaga listrik $20 \mathrm{KV}$ yang disuplai melalui dua gardu induk, yakni Gardu Induk Bitung $\{70 \mathrm{KV}\}$ yang menyuplai 6 penyulang dan Gardu Induk Tanjung Merah $\{150 \mathrm{KV}\}$ yang menyuplai 3 penyulang. Salah satu penyulang yang disuplai dari Gardu Induk Tanjung Merah yakni penyulang Beta (SJ.2) saat ini berada dalam kondisi yang hampir kritis yang berarti sudah 
harus segera diperbaiki. Dimana tegangan pada ujung penyulang Beta (SJ-2) ini sudah hampir mencapai batas kritis jatuh tegangan sebesar $10 \%$ sesuai SPLN- 72: 1987.

Penyulang Beta (SJ-2) ini terletak pada sisi bagian barat Kota Bitung yang mencakup 3 Kecamatan, yakni : Matuari, Ranowulu dan Girian dengan panjang jaringan mencapai $\pm 53.64 \mathrm{KMc}$ dengan jalur pendistribusian $\{150 \mathrm{KV}\}$ melalui Gardu Induk Paniki yang kemudian di distribusikan ke pelanggan yang tersebar pada Penyulang Beta (SJ2) melalui Transformator yang ada pada Gardu Induk Tanjung Merah dengan kapasitas $\{30$ MVA $\}$. Penyulang Beta (SJ-2) ini mempunyai beban 5.864 MW dan beban 4.048 MVAr dengan 117 Gardu distribusi yang tersebar dalam Penyulang Beta (SJ-2), dari 117 Gardu Distribusi tersebut, terdapat 34 unit Gardu Distribusi yang sudah mendekati batas kritis tegangan - (kurang) atau biasa disebut dengan jatuh tegangan 10 $\%$ atau $2 \mathrm{Kv}$ dari Tegangan Jaringan Distribusi $\{20 \mathrm{Kv}\}$ sesuai SPLN- 72: 1987.

\section{TINJAUAN PUSTAKA DAN LANDASAN TEORI}

Penelitian ini dilakukan berdasarkan dengan fakta yang ditemukan oleh penulis langsung dilapangan pada saat penulis sedang melakukan kerja praktek dan juga di dukung dengan data pada penyulang Beta (SJ.2) yang diambil di PT. PLN (Persero) Rayon Bitung dan juga data beban puncak serta Single Line Diagram penyulang Beta (SJ-2) yang diambil di Gardu Induk (GI) Tanjung Merah.

Penelitian yang hampir serupa juga dilakukan oleh Rifqi Fakhrusy Ilman dengan judul Simulasi Dan Analisa Pemotongan Beban Penyulang Ayu GI Cikande, dimana masalah yang dialami adalah kepadatan beban yang tergolong tinngi, dimana pelanggan penyulang ayu ini mengalami lama padam rata-rata selama 29,28 jam / tahun, dimana standarnya adalah hanya 12,8 jam / pertahun (SPLN No 68-2 Tahun 1986 Standar LPR yaitu 12,8 jam per tahun). Oleh Karena itu diperlukan pemotongan beban dimana penulis memilih menggunakan 2 alternatif yang memungkinkan untuk dilakukannya pemotongan beban yakni, penarikan jaringan baru yang menghasilkan nilai susut daya dan teganngan ujung yang lebih baik, sedangkan alternative yang lainnya adalah interkoneksi dengan penyulang Mila yang mana sama-sama 
dapat mengurangi lama padam rata-rata dan juga investasi yang lebih murah.

Penelitian tentang pecah beban ini juga pernah dilakukan oleh Redho Akbar Rineldy Tentang Analisa perbaikan susut tegangan dengan cara pemecahan beban di PT. PLN (PERSERO) Rayon Sekayu Penyulang Burgo GI Betung Berbasis Etap menyimpulkan bahwa Untuk mengurangi susut tegangan di jaringan dan meningkatkan kehandalan jaringan, pemecahan beban dilakukan pada penyulang burgo ini.Pemecahan beban ini dilakukan dengan memasang SUTM murni pada outgoing penyulang burgo sampai incoming GH Babat sejauh $33 \mathrm{~km}$ menggunakan penghantar A3CS 150 mm2. Dengan menggunakan sotware ETAP 12.6, pensimulasian pemecahan beban dilakukan dengan menggambar single line diagram penyulang burgo dan mengintegrasikan data di lapangan ke dalam software ETAP. Hasil analisa jaringan penyulang burgo sebelum pemecahan beban dengan menggunakan software ETAP 12.6 didapat nilai tegangan pada beban Air Balui sebesar $5.833 \mathrm{kV}$. Sedangkan setelah pemecahan beban didapat nilai tegangan meningkat pada beban Air Balui sebesar $7.541 \mathrm{kV}$.

Sistem Tenaga Listrik dikatakan sebagai kumpulan/gabungan yang terdiri dari komponen-komponen atau alat-alat listrik seperti generator, transformator, saluran transmisi, saluran distribusi dan beban yang saling berhubungan dan merupakan satu kesatuan sehingga membentuk suatu sistem. Didalam dunia kelistrikan sering timbul persoalan-persoalan teknis, dimana tenaga listrik pada umumnya dibangkitkan pada tempattempat tertentu yang jauh dari kumpulan pelanggan, sedangkan pemakai tenaga listrik atau pelanggan tenaga listrik tersebar disegala penjuru tempat, Dengan demikian maka penyampaian tenaga listrik dari tempat dibangkitkannya yang disebut pusat tenaga listrik sampai ke tempat pelanggan memerlukan berbagai penanganan teknis.

\section{METODE PENELITIAN}

Pada tahap ini peneliti melakukan pengumpulan data pada penyulang jaringan tegangan menengah yang disuplay dari pembangkit GI Tanjung Merah serta melakukan pengukuran arus pangkal dan arus ujung yang diukur lewat gardu distribusi sisi sekunder pada penyulang. Setelah data terkumpul maka dilakukan perhitungan untuk mendapatkan nilai jatuh tegangan pada tiap-tiap trafo saluran JTM sistem distribusi tenaga listrik 
Penyulang Beta (SJ-2) PT PLN (PERSERO) Rayon Bitung yang kemudian akan dilakukan pengkajian penentuan Alternatif terhandal dengan melakukan simulasi pada Software ETAP 12.6 berdasarkan data yang telah diambil pada PT PLN (PERSERO) Rayon Bitung.

\section{HASIL DAN PEMBAHASAN}

PT PLN (Persero) Wilayah SULUTTENGGO Rayon Bitung Area Manado merupakan BUMN yang menyediakan tenaga listrik bagi seluruh lapisan masyarakat yang semakin hari semakin dibutuhkan keberadaannya. Hal ini tidak lepas dari kebutuhan masyarakat akan tenaga listrik yang semakin meningkat seiring dengan meningkatnya kemajuan teknologi dan taraf hidup masyarakat pada umumnya. PT PLN (Persero) Rayon Bitung Area Manado secara sistem terinterkoneksi dengan sistem SULUTGO melalui Gardu Induk Bitung dan Gardu Induk Tanjung Merah. Unit PT PLN (Persero) Rayon Bitung Area Manado dengan wilayah kerja meliputi Kecamatan Bitung Timur, Bitung Tengah, Bitung Barat, Maesa, Girian, Ranowulu dan Matuari.
PT PLN (PERSERO) Rayon Bitung sendiri dalam upaya menyediakan, mendistribusikan dan menjaga kestabilan kontinuitas tenaga litrik bagi seluruh lapisan masyarakat memiliki 9 penyulang yang disuplai melalui 2 Gardu Induk, yakni: Gardu Induk Bitung yang memiliki 2 buah Trafo $\{20$ dan $30 \quad$ MVA $\}$ yang menyuplai 6 penyulang (SI-1, SI-2, SI3, SI-4, SI-5 dan SI-6) kemudian Gardu Induk Tanjun Merah \{30 MVA\} yang Menyuplai penyulang (Alfa, Beta dan Charli).

\section{Keadaan Awal Penyulang Beta (SJ-2)}

Berdasarkan pada data yang diambil oleh penulis sewaktu melaksanakan penelitian di wilayah system kelistrikan PT PLN (PERSERO) Rayon Bitung dengan cara mengukur arus yang ada di sisi sekunder Trafo distribusi pada penyulang Beta (SJ-2) ini, yang kemudian di simulasi dengan menggunakan Software ETAB 12.0 dapat memperoleh Nilai Voltage Drop sebesar:

Berdasarkan hasil simulasi bahwasanya ada 34 Gardu yang sudah melewati batas minimun $-5 \%$ untuk Tegangan Jaringan Menengah. Drop 
Tegangan pada penyulang Beta (SJ-2) ini terjadi pada mulai dari titik gardu MBG-84 (Danaudu) hingga ke gardu ujung pada MBG-117 (Pinilih II) dan gardu ujung pada MBG-93 (Sisipan Dua Sudara). Berdasarkan data ini dapat disimpulkan bahwa total 34 gardu tersebut sudah mendekati batas toleransi yang diijinkan sesuai standar PLN yakni $+5 \%$ dan $-10 \%$ dan sudah harus segera diperbaiki sebelum masuk kedalam masa kritis.

\section{Kajian Kelayakan Operasi Pecah Beban Penyulang Beta SJ-2)}

Kajian Kelayakan Operasi adalah suatu langkah yang dilakukan sebelum melaksanakan suatu pekerjaan guna meminimalisir kerugian atau kegagalan saat pengoperasian pekerjaan yang dilakukan. Pada penyulang Beta (SJ-2) ini akan dilaksanakan pemecahan beban guna menanggulangi Voltage Drop atau Tegangan Jatuh yang terjadi dengan cara membagi beban penyulang menjadi 2 wilayah atau MengUprating kapasitas penghantar jaringan dengan cara mengganti kawat penghantar ke penampang yang lebih besar daya hantar Arusnya. Semua alternatif konstruksi akan dimulai dari Gardu Hubung (GH) Manembo-nembo.
Berdasarkan hasil simulasi setelah dilakukan pecah beban pada penyulang Beta (SJ-2) dengan menggunakan Alternatif Overshock jaringan, dapat disimpulakn bahwa pada awalnya gardu yang mengalami Drop tegangan yang melebihi $5 \%$ mencapai 34 unit berkurang menjadi 15 unit yang berarti Alternatif Overshock Jaringan dapat memperbaiki 19 unit gardu distribusi yang mendekati batas kritis.

\section{KESIMPULAN}

Berdasarkan hasil pembahasan pada BAB sebelumnya tentang mengatasi permasalahan Drop Voltage (Tegangan Jatuh) pada penyulang BETA (SJ-2) dengan menggunakan tiga Alternatif yakni Overshock, Uprating dan Pembangunan Jaringan Baru. Dengan cara di simulasikan dalam Software ETAP 12.6 maka penulis mengambil kesimpulan yakni:

1. Berdasarkan hasil kajian dengan menggunakan Software ETAP 12.6 maka didapati hasil untuk menanggulangi tegangan yang sudah mendekati zona kritis (Critical) yang ada pada penyulang BETA (SJ-2) ini dengan menggunakan Alternatif ke pertama yaitu Overshock Jaringan dengan keadaan tegangan ujung 
mencapai $18.861 \mathrm{KV}$ pada gardu distribusi MBG-117 (Desa Pinilih II)

2. Berdasarkan hasil kajian dengan menggunakan Software ETAP 12.6 maka didapati hasil untuk menanggulangi tegangan yang sudah mendekati zona kritis (Critical) yang ada pada penyulang BETA (SJ-2) ini dengan menggunakan Alternatif ke kedua yaitu Uprating Jaringan dengan keadaan tegangan ujung mencapai 18.871 KV. Pada gardu distribus MBG-117 (Desa Pinilih II)

3. Berdasarkan hasil kajian dengan menggunakan Software ETAP 12.6 maka didapati hasil untuk menanggulangi tegangan yang sudah mendekati zona kritis (Critical) yang ada pada penyulang BETA (SJ-2) ini dapat menggunakan Alternatif ke Tiga yaitu Pembangunan Jaringan Baru dengan keadaan tegangan ujung mencapai 19.053 KV. Pada gardu distribusi MBG-117 (Desa Pinilih II)

\section{DAFTAR PUSTAKA}

[1] Bachari E.P Yuzlizar, 2017, "Analisis Jatuh Tegangan Dan Rugi - Rugi Daya Pada Penyulang Tegangan Menengah $20 \mathrm{Kv}$ Sistem Distribusi Area Kotamobagu Yang Disuplay Dari Pltd Kotamobagu”

[2] _Erifur Aranny Zaikal, 8008027 Z, 2015, "Pembuatan Kajian KelayakanTeknik Untuk Interkoneksi SUTM 20 KV PLTM Buleleng - Sub Rayon Laveu Kecamatan Bahodopi Dalam Melayani Kelistrikan Dan Sambung Baru Masyarakat Kecamatan Bahodopi”. Laporan Project Assigment, PLT Manajer Rayon Bungku.

[3] Hilman Fakhruzi Rizki, 2015, "Simulasi Dan Analisa Pemotongan Beban Penyulang Ayu GI Cikande" Jurnal Teknik Elektro, Fakultas Teknik, Universitas Mercubuana

[4] Rineldy Akbar Redho, 2015, "Analisa Perbaikan Susut Tegangan Dengan Cara Pemecahan Beban Di Pt. Pln (Persero) Rayon Sekayu Penyulang Burgo Gi Betung Berbasis Etap" Teknik Elektro Program Studi Teknik Listrik, Politeknik Negeri Sriwijaya. 